\title{
ISOLASI DAN IDENTIFIKASI KAPANG PADA PINDANG BANDENG (Chanos chanos) PRESTO
}

\section{ISOLATION AND IDENTIFICATION OF MOLD FROM BOILED SALTED MILK FISH (Chanos chanos)}

\author{
Resmi Rumenta Siregar \\ Sekolah Tinggi Perikanan \\ Jl. AUP No. 1 Pasar Minggu, Jakarta Selatan. Telp: 7805030, Faks. 7805030 \\ E-mail: resmi.siregar@gmail.com
}

(Diterima: 12 Maret 2019; Diterima setelah perbaikan: 19 Juli 2019; Disetujui: 19 Juli 2019)

\begin{abstract}
ABSTRAK
Ikan pindang adalah salah satu olahan yang sangat disukai oleh masyarakat Indonesia. Hal ini dapat dilihat dari produksi ikan pindang yang setiap tahunnya mengalami peningkatan. Sebagai contoh di Kabupaten Bogor, produksi ikan pindang pada tahun 2013 sebesar 3.643,56 ton, meningkat menjadi 10.334,44ton pada tahun 2015. Ikan pindang disisi lain, sangat mudah mengalami kemunduran mutu disebabkan masih tingginya kadar air, pengemasan yang tidak memenuhi standar serta proses pengolahan yang pada umumnya kurang menerapkan prinsip sanitasi yang baik. Penelitian ini bertujuan untuk mengisolasi dan mengidentifikasi kapang yang tumbuh pada bandeng presto. Sampel Bandeng presto diambil dari CV. Cindy Group. Kapang diisolasi dengan metode pengenceran bertingkat menggunakan media DRBC (Dichloran Rose Bengal Chloramphenicol Agar), kemudian diidentifikasi secara morfologi menggunakan media Malt Extract Agar dan Czapek's Yeast Extract Agar. Nilai Aktivitas air $\left(\mathrm{a}_{\mathrm{w}}\right)$ bandeng presto memiliki kisaran rata-rata $0,96-0,97$. Secara makroskopis terlihat adanya pertubuhan kapang pada permukaan ikan bandeng presto setelah penyimpanan selama 3 hari pada suhu ruang $\left(20-25^{\circ} \mathrm{C}\right)$. Sebanyak 5 isolat kapang diisolasi dari ikan pindang sampel bandeng presto. Hasil identifikasi secara mikroskopis diketahui bahwa kapang yang tumbuh ada ikan pindang tersebut adalah spesies Penicillium citrinum, Eurotium chevalieri, Fusarium solani, Fusarium sp, dan Cladosporium sp. Kadar aw ikan pindang resto yang masih tinggi $(0,96-0,97)$ menyebabkan ikan pindang mengalami pembusukan yang diakibatkan oleh bakteri.
\end{abstract}

KATA KUNCI: Isolasi; identifikasi; kapang; pindang

\begin{abstract}
Pindang is one of the favorite traditional fish products in Indonesia. It can be seen from total productions of pindang which is increase every year. Specially in Bogor regency, pindang productions increase from 3.643,56 ton in 2013 to $10.334,44$ ton in 2015. On the other hand, pindang as well as fresh fish is a perishable food because of it's characteristic (high moisture content, unproper packaging and lack of good sanitation and hygiene practices during production). The aim of this study was to determine mold species, isolated from presto salted milkfish. Presto salted milkfish was taken from CV. Cindy group. Isolation of mold was carried out by serial dilution method, using DRBC (Dichloran Rose Bengal Chloramphenicol Agar) medium, and morphology identification using Malt Extract Agar dan Czapek's Yeast Extract Agar medium. Water activity were examined as the support data, the aw content is 0,96-0,97. After 3 days keep at room temperature $\left(20-25^{\circ} \mathrm{C}\right)$, shown the growth of mold on the surface of presto salted fish. A total of 5 mold isolates from presto salted fish. The microscopic identification shown that these isolates belong to 5 species as follow: Penicillium citrinum, Eurotium chevalieri, Fusarium solani, Fusarium sp, and Cladosporium sp. Water activity (aw) of boiled salted fish was still high, so the bacterial spoilage occur prior to growth of mold.
\end{abstract}

KEYWORDS: Isolation: identification; mold; pindang

\footnotetext{
\# Korespondensi: Sekolah Tinggi Perikanan
}

E-mail: resmi.siregar@gmail.com 


\section{PENDAHULUAN}

Pemindangan ikan merupakan salah satu cara pengolahan ikan dengan kombinasi perlakuan antara penggaraman dengan perebusan. Terdapat tiga macam proses pemindangan, yaitu pemindangan air garam (naya), pemindangan garam (badeng/paso) dan pemindangan presto (Wibowo, 1996). Pengolahan pindang presto bertujuan menghasilkan pindang berduri lunak serta waktu pemasakan yang singkat (Hartatik, 2007). Pada prinsipnya pengolahan presto tidak jauh berbeda dengan pemindangan, yaitu pengolahan ikan melalui penggaraman yang dikombinasikan dengan perebusan, namun menyebabkan tulang dan durinya dalam keadaan lunak karena perlakuan suhu dan tekanan tinggi seperti pada pengalengan. Ikan yang biasanya di olah dengan metode presto adalah ikan bandeng. Hal ini dilakukan untuk mengatasi duri ikan bandeng yang jumlahnya banyak agar dapat dengan mudah dikonsumsi.

Pengolahan ikan pindang di Indonesia sebagian besar belum menerapkan sanitasi dan higiene dengan baik, sehingga produk yang dihasilkan bermutu rendah (Thaheer, Hasibuan, \& Mumpuni, 2015) dan cenderung mudah mengalami kerusakan, yang salah satunya disebabkan oleh pertumbuhan kapang (Ariyani \& Yennie, 2008). Dengan demikian ikan pindang mempunyai daya awet yang relatif pendek yaitu berkisar 1-3 hari (Irianto \& Pratiwi, 2009; Nasran,1980 dalam Ariyani \& Yennie, 2008) atau 2-7 hari (Gopakumar, 1977 dalam Ariyani \& Yennie, 2008; Irianto \& Pratiwi, 2009). Bahkan pindang bandeng dengan perlakuan presto yang disimpan pada suhu ruang mempunyai daya simpan hanya tiga hari (Kusumayanti, et al. 2011).

Faktor yang sangat berpengaruh terhadap penurunan mutu produk pangan adalah perubahan kadar air dalam produk. Aktivitas air (aw) berkaitan erat dengan kadar air, yang umumnya digambarkan sebagai kurva isotermis, serta pertumbuhan bakteri, jamur dan mikroba lainnya. Makin tinggi aw pada umumnya makin banyak bakteri yang dapat tumbuh, sementara kapang tidak menyukai aw yang tinggi (Christian 1980 dalam Herawati, 2008).

Kapang merupakan mikroorganisme eukariotik, tidak berklorofil, memiliki hifa, dinding sel terdiri dari kitin atau selulosa, serta berkembang biak secara seksual dan aseksual (Gandjar, Samson, \& Vermeulen, 1999; Pitt \& Hocking, 2009; Rahayu et al 2016). Kapang pada umumnya hidup secara aerob, tumbuh optimal pada kisaran suhu $25-30{ }^{\circ} \mathrm{C}$ dan dapat tumbuh pada kisaran pH yang cukup luas yaitu 2,0-8,5 meskipun pada kenyataannya kapang lebih suka pada kondisi asam, Winarno, (1994) dalam Agustin (2016); Pitt \& Hocking, (2009). Kapang mampu tumbuh dengan baik pada kisaran aw 0,65-0,95 (Pitt \& Hocking, 2009; Rahayu et al., 2014) atau 0,60-0,70 (Rahayu \& Nurwitri, 2012). Kapang dapat menyebabkan pembusukan bahan pangan. Selain itu produksi zat-zat racun yang dihasilkan berbagai jenis kapang yang tumbuh pada bahan pangan dapat diduga memberi ancaman bahaya bagi kesehatan masyarakat. Telah ditemukan beberapa kapang yang mencemari dan tumbuh pada produk bahan pangan menghasilkan zat-zat racun yang dikenal sebagai mycotoxin. Mycotoxin didefinisikan sebagai zat yang diproduksi oleh kapang dalam bahan pangan yang dapat menyebabkan penyakit atau kematian bila termakan oleh manusia. Rahmadi dan Fleet (2008) melaporkan jenis-jenis kapang yang menghasilkan toksin antara lain adalah Aspergillus flavus, $A$. parasiticus, dan $A$. niger, sedangkan menurut Maryam (2007) kapang toksigenik yaitu Aspergillus sp. dan Fusarium sp. Lebih lanjut Rahayu et al (2014), mengatakan bahwa akibat dari konsumsi cemaran mikotoksin ini secara terus menerus dapat mengakibatkan penurunan kesehatan yaitu penurunan daya tahan tubuh, mudah terserang penyakit, pertumbuhan yang lambat pada anak-anak, munculnya kanker, kerusakan liver bahkan sampai pada kematian. Mikotoksin adalah toksin yang sangat stabil, dan tidak bisa dihilangkan sama sekali dari berbagai proses pengolahan.

Penelitian mengenai isolasi dan identifikasi kapang pada ikan pindang di Indonesia sudah banyak dilakukan. Indriati et al (2008) yang melakukan isolasi dan identifikasi pada pindang ikan tongkol memperoleh jenis-jenis kapang $A$. flavus, $A$. niger, $A$. ochraceus, $P$. chrysogenum, dan Rhyzopus oryzae. Beberapa di antaranya berpotensi menghasilkan toksin. Lebih lanjut Hermana et al. (2018), mengisolasi dan mengidentifikasi kapang dari ikan pindang, dan berhasil mengisolasi 16 jenis kapang yaitu Aspergillus flavus, A. fumigatus, A. niger, A. ochraceus, A. oryzae, $A$. sydowii, $A$. terreus, Cladosporium allicinum, Eurotium chevalieri, Fusarium graminearum, F. cerealis, Loweporus sp., Penicillium citrinum, P. chermesinum, P. chrysogenum, dan Syncephalastrum racemosum. Namun sejauh ini identifikasi kapang pada pindang dengan perlakuan presto belum banyak dilakukan, oleh karena itu, penelitian ini dilakukan untuk memperoleh informasi mengenai jenis kapang yang tumbuh pada ikan pindang presto.

\section{BAHAN DAN METODE}

Peralatan yang untuk pengujian aktivitas air (aw) adalah aw meter (Dew Point Water Activity Meter). Peralatan yang digunakan untuk isolasi dan identifikasi kapang adalah disposable petri dish, labu erlenmeyer 1L dan $500 \mathrm{~mL}$, mikroskop (Olympus CX21-FX), lampu spritus , pipet tip, micro pipet, rak tabung, gelas ukur, 
kaca objek, kaca penutup, tusuk gigi, gunting, timbangan analitis (vibra), kertas label, jarum ose, jarum tanam tajam, pinset, penggaris, autoclave (kemoto scientific), laminary air flow (telstar), pengaduk magnetik, hotplate stirrer (thermo scientific), dan kamera digital (Canon EOS). Bahan yang digunakan dalam identifikasi kapang adalah bandeng presto yang diperoleh dari pengolah di CV. Cindy Group. Media untuk isolasi adalah DRBC (Dichloran Rose Bengal Chloramphenicol), untuk identifikasi adalah Malt Extract Agar (MEA) dan Czapek's Yeast Extract Agar (CYA); sedangkan untuk pengencer digunakan $\mathrm{NaCl}$ 0,85\% dan aquades. Bahan kimia yang digunakan adalah alkohol $70 \%$, minyak imersi dan lactophenol cotton blue.

\section{Preparasi sampel}

Sampel diambil dari pengolah bandeng presto di CV Cindy Group satu hari setelah diolah. Pengambilan sampel dilakukan 2 (dua) kali pengamatan, masingmasing sebanyak 6 (enam) ekor setiap kali pengamatan.

\section{Isolasi kapang}

Kapang diisolasi dari sampel bandeng presto dengan mengacu pada BSN (2009) menggunakan metode pengenceran bertingkat, kemudian ditumbuhkan pada medium Dichloran Rose Bengal Chlorampenicol (DRBC) Agar (Indriati et al., 2010; Pitt \& Hocking, 2009). Inkubasi kapang dilakukan pada suhu ruang $\left(25^{\circ} \mathrm{C}\right)$ selama tujuh hari. Pemilihan isolat pada tahap awal identifikasi dilakukan berdasarkan perbedaan warna dan tekstur koloni yang tumbuh dengan pengamatan secara morfologi pada media DRBC.

\section{Identifikasi kapang}

Identifikasi kapang dilakukan secara morfologi (makroskopis dan mikroskopis). Pengamatan secara morfologi dilakukan dengan mengamati warna dan tekstur koloni. Setiap koloni yang memiliki warna serta tekstur yang berbeda ditanam kembali dengan menggunakan media Malt Extract Agar (MEA) dan Czapek's Yeast Extract Agar(CYA). Pengambilan spora kapang dilakukan dengan menggunakan jarum ose yang sudah disterilkan terlebih dahulu dan ditanam pada media. Masing-masing media diinkubasi pada suhu ruang, dan dilakukan pengamatan pada hari ke 5 sampai hari ke-7. Kapang yang tumbuh, kemudian diidentifikasi secara makroskopis dan mikroskopis. Identifikasi makroskopis meliputi warna permukaan koloni, warna sebalik (reverse side), tekstur koloni dan diameter kapang. Sedangkan identifikasi secara mikroskopis dilakukan dengan menggunakan larutan lactophenol blue, kemudian koloni kapang diambil secukupnya, dan diamati dibawah mikroskop dengan perbesaran $100 \mathrm{x}$. Identifikasi dilakukan menurut (Rahayu et al., 2014), dan (Pitt \& Hocking, 2009).

\section{HASIL DAN PEMBAHASAN}

Aktivitas air (aw) bandeng presto adalah berkisar antara 0,9608-0,9699. Aktivitas air (Aw) merupakan salah satu faktor menggambarkan banyaknya air bebas pada produk yang dapat digunakan untuk aktivitas biologis mikroorganisme. Bahan pangan dengan kadar air tinggi (nilai aw: 0,95-0,99) umumnya dapat ditumbuhi oleh semua jenis mikroorganisme, tetapi karena bakteri dapat tumbuh lebih cepat daripada kapang dan khamir, maka kerusakan akibat bakteri lebih banyak dijumpai (Buckle et al, 2013).

Penyimpanan bandeng presto selama 3 hari pada suhu ruang $\left(20-25^{\circ} \mathrm{C}\right)$ terlihat secara makrokopis telah ditumbuhi kapang di dipermukaannya. Warna kapang yang paling dominan tumbuh adalah berwarna putih dan memiliki tekstur seperti kapas.

\section{Isolasi kapang}

Hasil isolasi kapang pada media DRBC, dari 12 sampel bandeng presto yang diisolasi terdapat 6 sampel bandeng presto yang ditumbuhi kapang. Hal ini kemungkinan berasal dari kontaminasi lingkungan akibat penerapan sanitasi yang kurang mulai dari proses pemasakan sampai ke pemasaran. Hal ini sesuai dengan Indriati et al. (2008) yang mengatakan bahwa pada umumnya kontaminasi spora kapang pada ikan pindang berasal dari lingkungan sekitar pengolahan dan wadah/ peralatan yang digunakan dalam pengolahan. Lebih lanjut Nasran (1980) dalam Seila (2014) mengatakan bahwa masalah utama pada ikan pindang adalah tumbuhnya kapang. Hasil penelitian Hermana et al. (2018) dijelaskan bahwa dari beberapa lokasi yang diobservasi, jumlah isolat kapang tertinggi diperoleh dari ikan pindang yang berasal dari Jakarta. Hal ini kemungkinan disebabkan karena sampel ikan pindang yang diambil dari Jakarta sebagian besar diperoleh dari pengecer (pasar), di mana penjual pindang di tingkat pengecer pada umumnya berjualan langsung di lantai (tidak menggunakan meja) dan di dekat penjual sayuran, cabe, beras dan kacang. Menurut Rahayu et al. (2014) lingkungan pasar yang tidak higienis merupakan salah satu sumber kontaminasi paling besar. Hasil isolasi kapang pada media DRBC, didapatkan 5 jenis kapang yang memiliki warna dan tekstur yang berbeda. Total koloni kapang yang diperoleh adalah $10 \times 10^{3} \mathrm{koloni} / \mathrm{ml}$. Kapang-kapang tersebut dipindahkan ke media CYA dan MEA untuk diidentifikasi. 


\section{Identifikasi Kapang}

Hasil identifikasi secara makroskopis pada media CYA dan MEA, diperoleh 5 jenis kapang yang tumbuh pada bandeng presto yaitu: Penicillium citrinum,
Eurotium chevalieri, Fusarium solani, Fusarium sp, dan Cladosporium sp, dengan kenampakan seperti disajikan pada Gambar 1 dan karakteristik seperti pada Tabel 1.

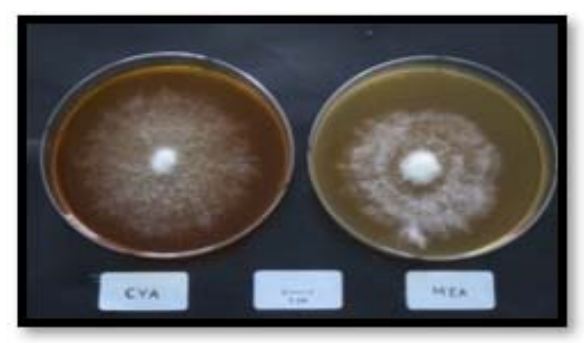

(a)

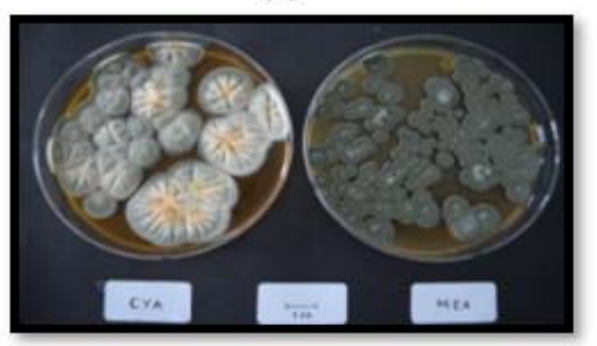

(c)

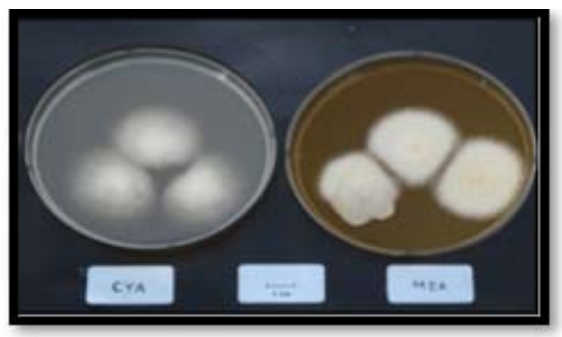

(b)

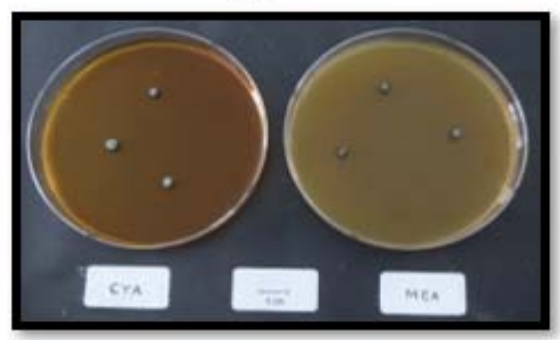

(d)

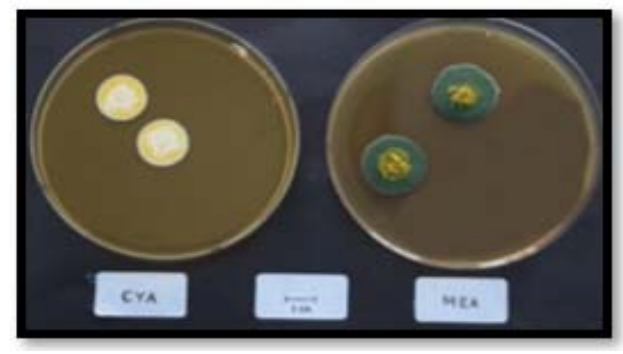

Sumber: Hasil pengamatan

Gambar 1. Koloni kapang hasil isolasi pada media CYA dan MEA: a. Fusarium solani, b. Fusarium sp, c. Penicillium citrinum, d. Cladosporium sp., e. Eurotium chevalieri.

Figure 1. Mold colony after isolation at CYA dan MEA medium: a. Fusarium solani, b. Fusarium sp, c. Penicillium citrinum, d. Cladosporium sp., e. Eurotium chevalieri.

\section{Fusarium sp}

Spesies fusarium terdistribusi diseluruh dunia, termasuk yang tergolong patogen pada tanaman pangan (gandum dan jagung). Kapang ini memberikan efek berupa timbulnya serabut berwarna putih pada permukaan bandeng presto. Koloni CYA berwarna putih, memiliki tekstur kapas (wooly), memiliki permukaan rata, warna sebalik koloni (reserse of colony) berwarna putih. Pada media MEA koloni berwarna putih, memiliki tekstur kapas (wooly), permukaan rata, warna sebalik koloni (reserse of colony) berwarna putih. Secara makrokopis terlihat bahwa Fusarium sp memiliki konidia bersepta, dan memiliki makrokonidia berbentuk sabit.
Hasil pengamatan karakter morfologi secara mikroskopis menunjukkan bahwa kapang tersebut termasuk ke dalam genus Fusarium sesuai dengan deskripsi kapang dalam Jamur Benang (Mold) pada Bahan Pangan oleh Rahayu et al. (2014). Menurut Rahayu et al. (2014), Karakter utama pada genus fusarium adalah produksi konidia bersepta, berbentuk fusiform, sampai berbentuk sabit yang disebut makrokonidia, dengan sel basal berbentuk seperti kaki dan sel puncak yang kurang lebih seperti paruh.

Fusarium sp menghasilkan mikotoksin dan mikotoksikosis yaitu trikotesena dan zearalenon. Trikotesena adalah racun dengan gejala awal seseorang menderita alimentary toxic aleukia merasakan mulut 
dan tenggorokannya seperti terbakar, kemudian tulang sum-sum dirusak, pendarahan patechial, dan berujung kematian. Zaeralenon merupakan toksik yang menyebabkan masalah pada hewan yang menimbulkan kerugian besar (Rahayu et al. 2014). Menurut Maryam (2007) kapang jenis Fusarium sp bersifat toksigenik.

Tabel 1. Karakteristik Makroskopis Koloni Kapang

Table 1. Macroskopic Characteristic of Mold Colony

\begin{tabular}{|c|c|c|}
\hline \multirow{2}{*}{$\begin{array}{l}\text { Jenis } \\
\text { Kapang }\end{array}$} & \multicolumn{2}{|c|}{ Ciri-ciri Makroskopis } \\
\hline & CYA & MEA \\
\hline Fusarium sp & $\begin{array}{l}\text { Berdiameter 2,0-2,5 cm, warna } \\
\text { putih, tekstur kapas (wooly), } \\
\text { permukaan tidak rata, tidak } \\
\text { memiliki growing zone, tidak } \\
\text { memiliki eksudate drop, tidak } \\
\text { memiliki zonation, tidak } \\
\text { memiliki radial furrow, warna } \\
\text { sebalik koloni putih. }\end{array}$ & $\begin{array}{l}\text { Memiliki diameter } 3,2-3,5 \mathrm{~cm} \text {, warna } \\
\text { koloni putih kekuningan, tekstur } \\
\text { kapas (wooly), permukaan rata, tidak } \\
\text { memiliki growing zone, tidak } \\
\text { memiliki eksudate drop, tidak } \\
\text { memiliki zonation, tidak memiliki } \\
\text { radial furrow, warna sebalik koloni } \\
\text { putih. }\end{array}$ \\
\hline $\begin{array}{l}\text { Fusarium } \\
\text { solani }\end{array}$ & $\begin{array}{l}\text { Memiliki diameter 6,5 cm, } \\
\text { warna koloni putih, tekstur } \\
\text { kapas (wooly), permukaan tidak } \\
\text { rata (menggunung di tengah), } \\
\text { tidak memiliki growing zone, } \\
\text { memiliki eksudate drop, tidak } \\
\text { memiliki zonation, tidak } \\
\text { memiliki radial furrow, warna } \\
\text { sebalik koloni } \\
\text { kekuningan. }\end{array}$ & $\begin{array}{l}\text { Memiliki diameter } 6 \mathrm{~cm} \text {, warna } \\
\text { koloni putih, tekstur kapas (wooly), } \\
\text { permukaan tidak rata, tidak memiliki } \\
\text { growing zone, tidak memiliki } \\
\text { eksudate drop, tidak memiliki } \\
\text { zonation, tidak memiliki radial } \\
\text { furrow, warna sebalik koloni putih } \\
\text { kekuningan. }\end{array}$ \\
\hline $\begin{array}{l}\text { Peniciliium } \\
\text { citrinum }\end{array}$ & 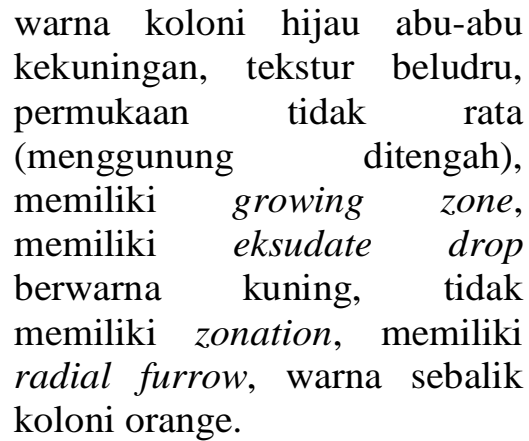 & $\begin{array}{l}\text { warna koloni hijau, tekstur beludru, } \\
\text { permukaan tidak rata, memiliki } \\
\text { growing zone, memiliki eksudate } \\
\text { drop, tidak memiliki zonation, } \\
\text { memiliki radial furrow, warna } \\
\text { sebalik koloni krem kekuningan. }\end{array}$ \\
\hline $\begin{array}{l}\text { Cladosporium } \\
\text { sp }\end{array}$ & $\begin{array}{l}\text { Memiliki diameter 0,4-0,5 cm, } \\
\text { warna koloni abu-abu, tekstur } \\
\text { beludru, permukaan tidak rata } \\
\text { (menggunung di tengah), tidak } \\
\text { memiliki growing zone, tidak } \\
\text { memiliki eksudate drop, tidak } \\
\text { memiliki zonation, tidak } \\
\text { memiliki radial furrow, warna } \\
\text { sebalik koloni hitam. }\end{array}$ & $\begin{array}{l}\text { Memiliki diameter } 0,5-0,6 \mathrm{~cm} \text {, warna } \\
\text { koloni abu-abu, tekstur beludru, } \\
\text { permukaan tidak rata (menggunung } \\
\text { di tengah), tidak memiliki growing } \\
\text { zone, tidak memiliki eksudate drop, } \\
\text { tidak memiliki zonation, tidak } \\
\text { memiliki radial furrow, warna } \\
\text { sebalik koloni hitam. }\end{array}$ \\
\hline $\begin{array}{l}\text { Eurotium } \\
\text { chevalieri }\end{array}$ & $\begin{array}{l}\text { Memiliki diameter } 1,9-2,1 \mathrm{~cm} \text {, } \\
\text { warna koloni kuning cerah, } \\
\text { tekstur beludru, permukaan } \\
\text { tidak rata, memiliki growing } \\
\text { zone, memiliki eksudate drop, } \\
\text { tidak memiliki zonation, } \\
\text { memiliki radial furrow, warna } \\
\text { sebalik koloni kecoklatan. }\end{array}$ & $\begin{array}{l}\text { Memiliki diameter } 0,9-1,8 \mathrm{~cm} \text {, } \\
\text { warna koloni kuning cerah, tekstur } \\
\text { beludru, permukaan tidak rata, } \\
\text { memiliki growing zone, memiliki } \\
\text { eksudate drop, tidak memiliki } \\
\text { zonation, memiliki radial furrow, } \\
\text { warna sebalik koloni kecoklatan. }\end{array}$ \\
\hline
\end{tabular}




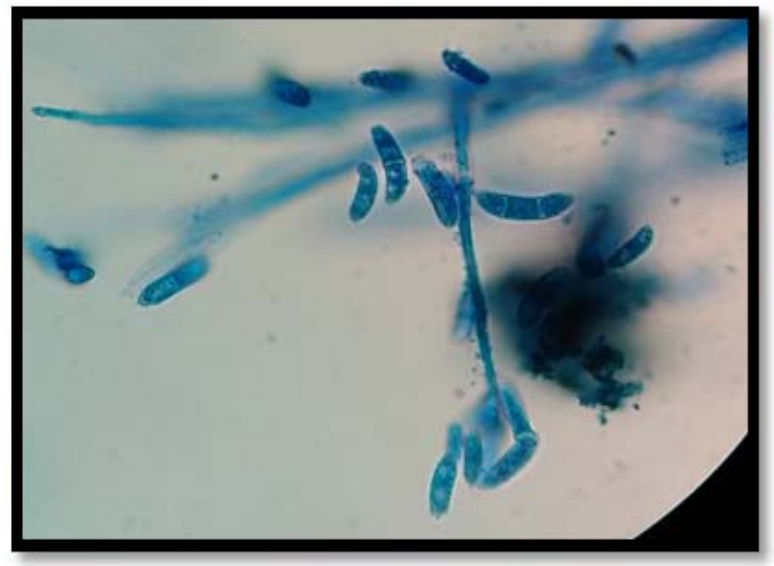

Sumber: Hasil pengamatan

Gambar 2. Fusarium sp pada 100 kali pembesaran.

Figure 2. Fusarium sp at 100 times enlargemen.

\section{Fusarium solani}

Fusarium solani adalah kapang yang umumnya terdapat di seluruh dunia baik pada bahan pangan maupun lingkungan sekitar ruangan. Kapang ini memberikan kenampakan pada permukaan bahan makanan yang rusak berbentuk kapas berwarna putih. Koloni pada media CYA berwarna putih, memiliki tekstur kapas (wooly), dengan permukaan yang tidak rata (menggunung ditengah), warna sebalik koloni (reserse of colony) berwarna putih kekuningan. Koloni ini sangat cepat mengalami pertumbuhan. Pada media MEA koloni kapang memiliki ukuran dengan diameter $6 \mathrm{~cm}$, berwarna putih, bertekstur kapas (wooly), memiliki permukaan tidak rata, warna sebalik koloni (reserse of colony) berwarna putih kekuningan. Kenampakan mikroskopis dari Fusarium sp adalah memiliki konidiofor panjang dan tidak bercabang, makrokonidianya membentuk bulan sabit. Fusarium solani dapat hidup dalam tanah maupun berbagai jenis tanaman dan hewan. Fusarium solani dapat memproduksi enzim, salah satunya yang sudah diteliti adalah enzim kutinase (cutinase) dan mengandung strain yang memiliki kemampuan mendegradasi berbagai jenis polutan organik dan pestisida (Rahayu et al., 2014).

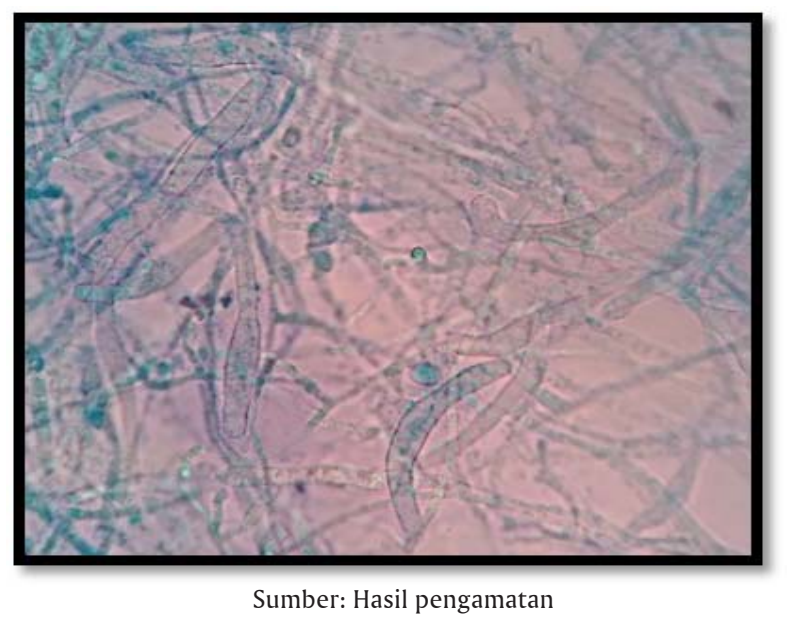

Gambar 3. Fusarium solani pada 100 kali pembesaran.

Figure 3. Fusarium soloni at 100 times enlargement.

\section{Penicilium Citrinum}

Pada media CYA, koloni berwarna hijau abu-abu kekuningan, memiliki tekstur beludru (seperti kain beludru), dengan permukaan yang tidak rata (menggunung ditengah), memiliki zona pertumbuhan (growing zone), memiliki titik-titik cairan (eksudate drop) berwarna orange, memiliki garis dari pusat koloni ke tepi (radial furrow), warna sebalik koloni (reserse of colony) berwarna orange. Pada medium MEA, koloni memiliki ciri-ciri berwarna hijau, 
bertekstur beludru (seperti kain beludru), memiliki permukaan tidak rata, memiliki zona pertumbuhan (growing zone), memiliki titik-titik cairan (eksudate drop) berwarna bening, memiliki garis dari pusat koloni ke tepi (radial furrow), warna sebalik koloni (reserse of colony) berwarna krem kekuningan. Secara makroskopis Penicillium citrinum terlihat memperlihatkan alat reproduksi aseksual (konidia), fialid, metula, konidiofor, dan hifa, konidia berbentuk bulat, memiliki tipe percabangan biverticillate. Menurut Rahayu et al. (2014), Penicillium citrinum memiliki konidiofora bivertisilata, berdinding halus. Sangat jarang monovertisilata, stipa berdinding halus. Fialida berbentuk silindris yang menyempit di bagian leher.

Penicillium Citrinum memiliki habitat dan fisiologi tergolong jamur pangan dan ruang (indoor fungI). $P$. Citrinum umumnya terdapat di daerah beriklim sedang, sub-tropis, dan terutama tropis. Kapang jenis ini dapat ditemukan pada berbagai jenis makanan, khususnya serealia tropis, spices dan pati sago dan juga didalam tanah maupun udara dalam ruangan. Veronika et al., (2015) menyatakan bahwa Penicillium sebagai penyebab kapang kelabu (grey mould) pada buah jeruk, dan dapat merusak buah-buahan di gudang penyimpanan. Berdasarkan penelitian Handajani et al., (2006), hasil identifikasi kapang terhadap petis udang komersial didapatkan hasil bahwa berbagai jenis jamur dapat tumbuh dan menghasilkan toksin. Mikotoksin yang dihasilkan oleh Penicillium citrinum adalah sitrinin. Sitrinin berpengaruh pada ginjal dan menyebabkan kerusakan tubuler yang serupa dengan penyakit ginjal glomerulonephrosis atau nephrosis. Wang et al. (2007) menjelaskan bahwa Penicillium sp. memiliki antibakteri yang sangat potensial untuk menghambat pertumbuhan bakteri pathogen. Lebih lanjut dijelaskan bahwa Sitrinin adalah antibakteri Gram positif tetapi tidak beracun pada Gram negatif (Rahayu et al., 2014).

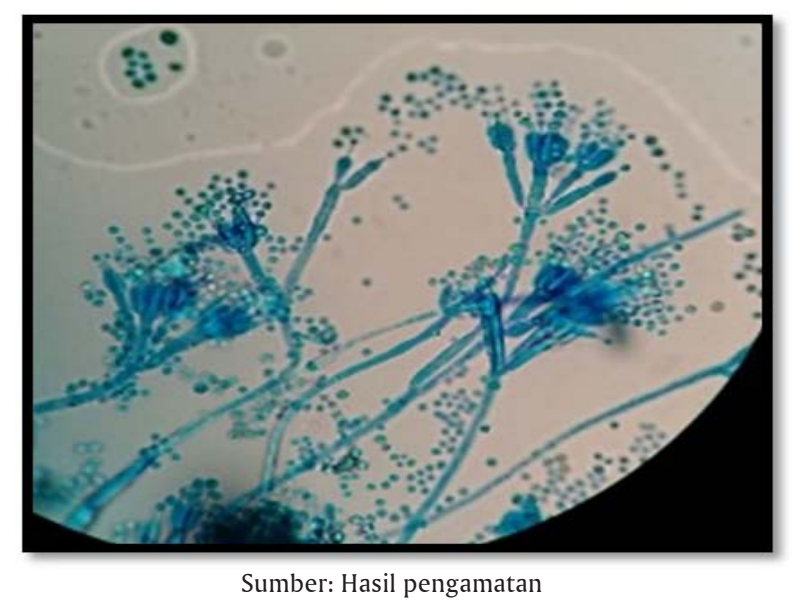

Gambar 4. Penicillium citrinum pada 100 kali pembesaran.

Figure 4. Penicillium citrinum at 100 times enlargement.

\section{Cladosporium sp}

Cladosporium $s p$ adalah jenis kapang yang tumbuh secara lambat. Pada media CYA, koloni kapang memiliki diameter 0,4-0,5 cm, memiliki pertumbuhan yang lambat, berwarna abu-abu, memiliki bentuk tekstur beludru (seperti kain beludru), permukaan tidak rata (menggunung), memiliki warna sebalik koloni (reserse of colony) berwarna hitam. Pada media MEA, koloni kapang memiliki diameter $0,5 \mathrm{~cm}$ $0,6 \mathrm{~cm}$, memiliki pertumbuhan yang lambat, memiliki warna koloni abu-abu, memiliki tekstur beludru (seperti kain beludru), permukaan tidak rata (menggunung), warna sebalik koloni (reserse of colony) berwarna hitam. Beberapa jenis toksin dapat dihasilkan dari kapang jenis Cladosporium, antara lain
C. cladosporoides (Fres.) de Vries merupakan spesies kapang patogenik karena dapat menghasilkan aflatoksin. Suriawiria (1986) dalam Qomariah et al. (2012) lebih lanjut menyatakan bahwa Aflatoksin yang dihasilkan bersifat hepatotoksik dan karsinogenik. Apabila biji kacang merah terkontaminasi oleh $C$. cladosporoides (Fres.) de Vries, maka dapat membahayakan bagi kesehatan.

\section{Eurotium chevalieri}

Eurotium chevalieri memiliki $\mathrm{a}_{\mathrm{w}}$ optimal untuk pertumbuhan 0,94-0,97. E. Chevalieri merupakan salah satu jamur pembusuk paling umum di bumi, terutama daerah yang lebih panas. Telah dilaporkan dapat menyebabkan pembusukan plum dengan kelembaban 
tinggi, pecan, mie tradisional Jepang, kue panggang semisoft, dan dilaboratorium, keju, kacang polong dan kacang faba (Pitt \& Hocking, 2009).

Pada media CYA koloni memiliki ciri-ciri berdiameter $1,9 \mathrm{~cm}-2,1 \mathrm{~cm}$, berwarna kuning cerah, memiliki tekstur beludru (seperti kain beludru), dengan permukaan tidak rata, memiliki zona pertumbuhan (growing zone), memiliki titik-titik cairan (eksudate drop), tidak memiliki garis radial (zonation), memiliki garis dari pusat koloni ke tepi (radial furrow), warna sebalik koloni (reserse of colony) berwarna kecoklatan. Koloni pada media MEA memiliki ciri-ciri yaitu berdiameter $0,9 \mathrm{~cm}-1,8 \mathrm{~cm}$, berwarna hijau, memiliki tekstur beludru (seperti kain beludru), memiliki permukaan yang tidak rata, memiliki zona pertumbuhan (growing zone), memiliki titik-titik cairan (eksudate drop) berupa titik-titik bening, tidak memiliki garis radial (zonation), memiliki garis dari pusat koloni ke tepi (radial furrow), warna sebalik koloni (reserse of colony) berwarna krem kekuningan. Hasil pengamatan karakter morfologi secara mikroskopis adalah sebagai berikut, struktur reproduksi aseksual berupa vesikel dan konidia berbentuk bulat, askus berbentuk bulat, dan memiliki konidiofor berbentuk panjang dan tidak bersepta. Eurotium chevalieri pernah dilaporkan memproduksi senyawa beracun, diidentifikasi sebagai echinulin dan neoechinulin, yang menyebabkan penolakan makanan pada babi. Namun, tes lain untuk racun dari $E$. Chevalieri adalah negatif (Pitt \& Hocking, 2009).

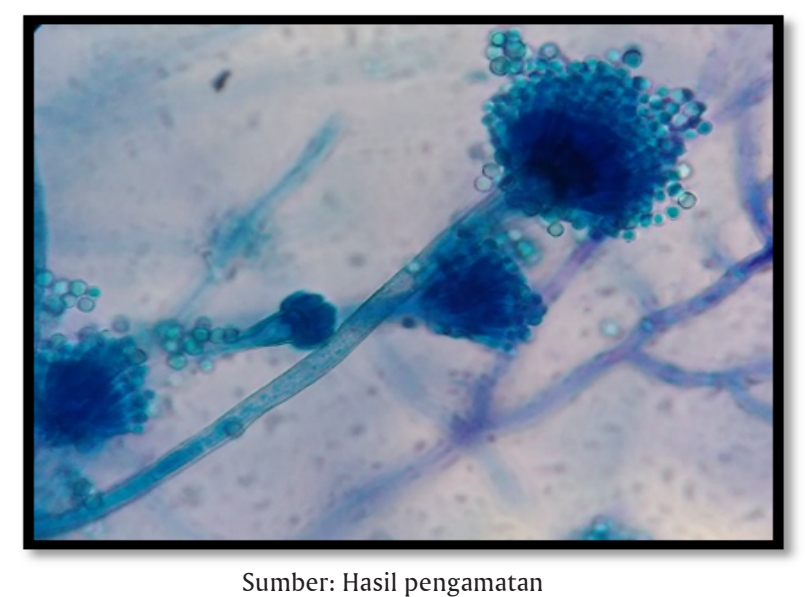

Gambar 5. Eurotium chevalieri pada 100 kali pembesaran.

Figure 5. Eurotium chevalieri at 100 times enlargement.

\section{KESIMPULAN DAN SARAN}

Hasil isolasi dan identifikasi kapang secara morfologi (makroskopis dan mikroskopis) dari ikan bandeng presto diperoleh 5 spesies, yaitu Penicillium citrinum, Eurotium chevalieri, Fusarium solani, Fusarium sp. dan Cladosporium sp.

\section{DAFTAR PUSTAKA}

Agustin, W. (2016). Inventarisasi dan Identifikasi Kapang pada Produk Ikan Asin. Skripsi. Universitas Nasional Jakarta, 81 pp.

Ariyani, F. \& Yennie, Y. (2008). Pengawetan Pindang Ikan Layang (Decapterus russelli) Menggunakan Kitosan. Jurnal Pasca panen dan Bioteknologi Kelautan dan Perikanan, 3 (2), 139-146.

Badan Standarisasi Nasional (BSN). (2009). SNI 2332.7 : 2009. Cara Uji Mikrobiologi- Bagian 7: Perhitungan Kapang \& Khamir Pada Produk Perikanan.
Buckle, K. A, Edwards R. A, Fleet G. H, Wootton M. (2013). Ilmu Pangan. Diterjemahkan oleh : Purnomo Hari dan Adiono. Jakarta: Penerbit Universitas Indonesia.

Gandjar, I., Samson, R.A., \& Vermeulen, K.V.D.T. (1999). Pengenalan Kapang Tropik Umum. Yayasan Obor Indonesia, Jakarta,

Hartatik, U. (2007). Penyimpanan ikan nila dan bandeng presto pada suhu dingin dalam wadah plastik polypropilene rigid kedap udara dan plastik polyethylene. Diakses 29 januari 2017, pukul 21:40.

Handajani, N.S., \& Setyaningsih, R. (2006). Identifikasi Jamur dan Deteksi Aflatoksin B1 terhadap Petis Udang Komersial. Biodiversitas, 7(3), 212-215.

Herawati, H. (2008) Penentuan umur simpan pada produk pangan. Jurnal Litbang Pertanian, 27(4), 124-130.

Hermana, I, Arifah, K \& Yusma, Y, (2018). Isolasi dan Identifikasi Kapang dari Ikan Pindang. JPB Kelautan dan Perikanan Vol. 13 No. 1 Tahun 2018: 81-92. 
Irianto, H. E. \& Pratiwi, Y. S. (2009). Chemical and Organoleptical Changes in Pindang Cue During Storage Ambient and Chill Temperatures. Journal of Marine and Fisheries Postharvest and Biotechnology - Special Edition in Conjunction with World Ocean Conference, 4, 67-72.

Indriati, N.,Supriadi, M. W. \& Salasa, F.F. (2008). Isolasi dan Identifikasi Jamur Pada Pindang Tongkol (Euthynnus Affinis). Jurnal Pascapanen dan Bioteknologi Kelautan dan Perikanan, 3(1), 11-20.

Indriati, N., Priyanto, N., Triwibowo, R. (2010). Penggunaan Dichloran Rose Bengal Chloramphenicol Agar (DRBC) Sebagai Media Tumbuh Kapang Pada Produk Perikanan. Jurnal Pasca panen dan Bioteknologi Kelautan dan Perikanan, 5(2), 117121.

Kusumayanti,H., Hartati, R., \& Supriyo, E. (2011). Aplikasi alat pengemas vacum pada industri bandeng presto di Semarang. Diakses 4 Februari 2017. Pkl 15:37.

Maryam, R. (2007). Metode Deteksi Mikotoksin. J. Mikot. Ked.Indon, 7(1-2),12-24.

Pitt, J.I., \& Hocking A.D. (2009). Fungi and food spoilage. London New York: Springer.

Qomariah U. K. Nur, Hastuti U.S, Witjoro Agung. (2012). Isolasi dan Identifikasi Kapang Kontaminan pada Biji Kacang Merah di Pasar Tradisional Kota Malang. Diakses 4 Februari 2017. Pkl 15:37.

Rahayu E.S., Sardjono, \& Samson, R.A. (2014). Jamur Benang (mold) pada bahan pangan. Yogyakarta: PT Kanisius.

Rahayu, W. P., \& Nurwitri, C. C. (2012). Mikrobiologi Pangan. IPB Press, Bogor.
Rahayu, E. S., Kamil, R. Z., Damara, Y., \& Sidar, A. (2016). The Occurance of Toxigenic Fungi in Indonesian Dried Food Product. International Commission on Food Mycologi (ICFM) Freising Germany. $38 \mathrm{pp}$

Rahmadi, \& Fleet. G. H. (2008). The Occurrence of Mycotoxygenic Fungi in Cocoa Beans from Indonesia and Queensland, Australia. Proceeding of International Seminar on Food Science, University of Soegiyopranata, Semarang, Indonesia. 118.

Seila, N. I. (2014). Determination of fungi and factors associated with their growth on sun dried Rastrine obolaargentea in Gucha South, Kisiicounty, Kenya. Thesis. Kenyatta University,

Thaheer, H., Hasibuan, S., \& Mumpuni, F. S. (2015). Model Resiko Keamanan Pangan Produk Pindang Pada UMKM Pengolahan Ikan Rakyat. Jurnal Pasti, 9 (3), 275-285.

Veronika., Mukarlina., \& Linda R. (2015). Jamur yang Diisolasi Dari Daun Dan Batang Bergejala Sakit Pada Tanaman Karet (Hevea brasiliensis Muell.Arg.) di Kabupaten Sanggau.

Wang F.W, Jiao R.H. Cheng A.B, Tan H.S., \& Song Y.C. (2007) Antimicrobial potential of endophytic fungi residing in Quercus variabilis and brefeldin A obtained from Cladosorium sp. World Journal of microbiology and Biotechnology. Januari $2007 \mathrm{Vol}$ 23, Issue 1, pp 79-83

Wibowo, S. (1996). Industri Pengolahan Ikan. Penebar Swadaya. Jakarta 